\title{
LIMBAH TEPUNG BATANG KANGKUNG (Ipomea aquatica) SEBAGAI BAHAN BAKU PAKAN IKAN NILA (Oreochromis nilotikus) DI KARAMBA
}

\author{
Sonny H. Marthen dan Cyska Lumenta \\ 'Fakultas Perikanan dan IImu Kelautan UNSRAT Manado, 95115
}

\begin{abstract}
Marthen, S.H. and C. Lumenta. 2006. The use Of un used Swampeabbage Stalk Flour (Ipomea aquatic) as Fed Raw Material for Neared For Nila Fish (Oreochormis niloticus) Cages (Karamba). Eugenia 12 (4) : 347-357.

This research was carried out at spp (Sekolah Pertanian Pembangunan) Manado Kalasey. The fishwere reared in karamba ( 9 units) each units contained 50 fish, 14-16 gr weight.

The experiment will be tested using completely random design using 3 deffierent tratment.One treatment is using comercial pellet and two treatmens all using pellets added with and swampcabbage stalk flour $20 \%$ and $30 \%$, each treatment hare 3 replicateris. Feeding frecuensi was 3 times aday and feeding
rate was $5 \%$ of their body weight the growth was observed every two weeks.

The result analysis from 3 treatment show that the relative growth of treatment A was (312.67\%) B was $(282.79 \%)$, and $C(262.41 \%)$ The was effisincy feeding foor treatment $A$ was hare $(49.43 \%)$, B was $48.78 \%$ and $C$ was $47.265 \%$ Where as nutient conversion rate of treatment $A$ was are $(0 \%), B$ was 3.47 $\%$, and $\mathrm{C}$ was $(3.82 \%)$.
\end{abstract}

Keywords : Swamp cabbage stalk flow (Ipomea aquatica) Nila gif, Karamba.

\section{PENDAHULUAN}

Usaha perikanan di Indonesia berperan penting dalam manunjang kebutuhan protein masyarakat melalui penyediaan bahan makanan. Budidaya ikan merupakan salah satu usaha perikanan untuk memelihara ikan dengan harapan hasil yang diperoleh lebih baik dibandingkan dengan hasil yang diperoleh dari ikan yang hidup secara alami (Sumantadinanta 1988).

Salah satu jenis biota perairan yang memiliki nilai ekonomis penting yaitu ikan nila. Ikan nila banyak dibudidayakan diberbagai daerah karena mempunyai kemampuan beradaptasi dengan baik, dapat tumbuh dengan cepat, bersifat omnivora, mampu mencerna makanan secara efisien dan mudah dalam penangananya (Suyanto 1995).

Menurut Christensen (1989), salah satu bentuk budidaya ikan yang paling intensif dilakukan adalah budidaya ikan dalam karamba. Mietode budidaya ini menjadi lebih terkenal di seluruh dunia karena tingkat keuntungan yang lebih tinggi dan mudah pengelolaannya.

Peningkatan produksi ikan mengacu pada ketersediaan pakan, karena pakan merupakan salah satu faktor penting dalam pengembangan budidaya ikan secara intensif. Untuk itu pakan yang digunakan harus berkualitas baik, mengan- 